\title{
Seagrass wasting disease along a naturally occurring salinity gradient
}

\author{
Stina Jakobsson-Thor*, Gunilla B. Toth, Henrik Pavia \\ Department of Marine Sciences - Tjärnö, University of Gothenburg, 45296 Strömstad, Sweden
}

\begin{abstract}
In the 1930s, outbreaks of the wasting disease pathogen Labyrinthula zosterae caused a severe reduction of the eelgrass Zostera marina meadows in the Atlantic Ocean. Many surviving populations were found in low-salinity environments, and low-salinity environments have therefore been hypothesized to act as a refuge for eelgrass against $L$. zosterae infection. Here, we investigated L. zosterae pathogen load and wasting disease symptoms in eelgrass over a $\sim 970 \mathrm{~km}$ salinity gradient (6-25 PSU) along the Swedish coast. Furthermore, laboratory infection experiments and studies of inhibitory compounds were carried out to investigated whether resistance against the pathogen is correlated to differences in natural pathogen pressure among eelgrass populations. The degree of $L$. zosterae infection was positively correlated to salinity and the pathogen was absent in several of the eelgrass meadows in lower salinity (7-8 PSU). However, a low L. zosterae pathogen load was also found in some eelgrass populations in the lowest salinity (6 PSU). No correlation between resistance and pathogen pressure in situ was detected, and all eelgrass shoots produced chemical compounds that inhibited L. zosterae growth. These results imply that positive correlations between $L$. zosterae and salinity are not due to eelgrass resistance, but rather to the poor ability of $L$. zosterae to cope with low salinity. However, our results also indicate that some strains of $L$. zosterae may adapt to low salinity, and therefore there may also be a risk of wasting disease outbreaks in low-salinity eelgrass meadows, in contrast to what so far has been the general hypothesis.
\end{abstract}

KEY WORDS: Labyrinthula zosterae - Zostera marina $\cdot$ Eelgrass $\cdot$ Chemical defense $\cdot$ Infection · Pathogen

\section{INTRODUCTION}

Marine pathogens can have devastating impacts on their hosts and the surrounding environment, and the effect can be harmful on the ecosystem level if the host is a keystone or foundation species (Harvell et al. 1999). One example of this is the seagrass wasting disease caused by the endophytic pathogen Labyrinthula zosterae D. Porter \& Muehlstein 1991, which in the past has been linked to large-scale seagrass die-offs (Petersen 1934, Renn 1935, Short et al. 1986, Muehlstein et al. 1991). This pathogen causes black necrotic lesions on seagrass leaves and is thought to have killed around $90 \%$ of the Zostera marina L. populations along the coasts of the Atlantic

*Corresponding author: sjakobsson87@gmail.com

$\S_{\text {Corrections were made after publication. For details see }}$ www.int-res.com/articles/meps_oa/m616p225.pdf This version: May 9, 2019
Ocean in the 1930s (Sullivan et al. 2013 and references within). Zostera marina is the dominant seagrass species in the northern hemisphere, where it forms a 3-dimensional habitat hosting a large diversity of invertebrate and fish species (Orth et al. 1984). This foundation species also provides a multitude of ecosystem services (Nordlund et al. 2016), including coastal protection (Barbier et al. 2011), and seagrass meadows constitute one of the most significant carbon sinks in coastal areas (Duarte et al. 2005).

Several environmental factors have been found to affect the degree of $L$. zosterae infection (see review by Sullivan et al. 2013), either through changes in $L$. zostera virulence or seagrass resistance to pathogens, but no single factor has been found to alter the

(C) The authors 2019. Open Access under Creative Commons by Attribution Licence. Use, distribution and reproduction are unrestricted. Authors and original publication must be credited.

Publisher: Inter-Research · www.int-res.com 
degree of infection to the level observed in the 1930s. One of the factors affecting L. zosterae infection is salinity (Young 1943, Muehlstein et al. 1988, Short et al. 1988). Laboratory studies have shown that Labyrinthula spp. lesions increase with higher salinity (Muehlstein et al. 1988, Burdick et al. 1993, McKone \& Tanner 2009), although hypersalinity (45 PSU) reduced lesion size in the sub-tropical seagrass Thalassia testudinum K. D. Koenig 1805 (Trevathan et al. 2011, Bishop et al. 2017). Labyrinthula spp. growth is greatly reduced at salinities below 10 PSU (Young 1943, Muehlstein et al. 1988, Martin et al. 2009). In contrast, Z. marina can tolerate lower salinities, and is naturally occurring in areas with average salinities of down to 5-7 PSU (Nejrup \& Pedersen 2008, Boström et al. 2014). Consequently, low-salinity environments, such as estuaries, have been hypothesized to act as a refuge for $Z$. marina from $L$. zosterae infection (Young 1943, McKone \& Tanner 2009, Jakobsson-Thor et al. 2018).

To our knowledge, only 2 studies have explicitly investigated the relationship between wasting disease and salinity in natural seagrass meadows (Burdick et al. 1993, Jakobsson-Thor et al. 2018). A yearlong field survey showed that disease generally increased during increasing salinity events in a $Z$. marina meadow in Great Bay, New Hampshire, USA, and that prolonged disease symptoms were sustained during salinities above 20 PSU (Burdick et al. 1993). Furthermore, in a field survey on the Swedish west coast, Jakobsson-Thor et al. (2018) found that the degree of infection on $Z$. marina shoots differed significantly between high- and low-salinity meadows separated by tens of kilometers, suggesting that low salinity decreases the pathogen pressure (pathogen concentration and disease symptoms) in the field on a relatively small geographical scale. Furthermore, Z. marina plants from high-salinity meadows were more resistant to L. zosterae infection compared to plants from low-salinity meadows, indicating that Z. marina populations on the Swedish west coast are locally adapted to L. zosterae (JakobssonThor et al. 2018). However, no study has investigated if this pattern also applies to larger geographical salinity gradients in natural $Z$. marina populations. The long $(\sim 2400 \mathrm{~km})$ Swedish coastline provides an excellent opportunity to investigate ecological patterns and evolutionary processes along a salinity gradient, from high salinity waters on the west coast to brackish environments in the Baltic Sea (Johannesson et al. 2011). In Swedish waters, Z. marina meadows are found at sites with salinities from 5 to 30 PSU (Boström et al. 2014, Jakobsson-Thor et al. 2018).
Labyrinthula zosterae has been detected in eelgrass meadows on the west coast of Sweden (Bockelmann et al. 2013, Jakobsson-Thor et al. 2018), but has not been studied in seagrass meadows along the Swedish coastline in the Baltic Sea.

One mechanism behind resistance against pathogens in marine organisms is the production of bioactive metabolites that function as chemical defenses (Hay \& Fenical 1988, Zidorn 2016). Inhibitory compounds against pathogenic Labyrinthula spp. have been isolated from the sub-tropical seagrass $T$. testudinum (Trevathan-Tackett et al. 2015) and from $Z$. marina (Jakobsson-Thor et al. 2018). However, the chemical nature of these metabolites has not been elucidated and chemical defenses against Labyrinthula spp. are still poorly understood. Labyrinthula zosterae infection can increase production of phenolic acids in seagrass (McKone \& Tanner 2009), a group of compounds that function as chemical defenses in terrestrial plants (Levin 1971). Phenolic acids inhibit Labyrinthula sp. growth at significantly lower concentrations than the ones measured in seagrass shoots (Trevathan-Tackett et al. 2015), indicating that they have other roles in the plant. Furthermore, the inhibitory effects of extracted $Z$. marina metabolites do not differ among shoots with different pathogen pressure in situ, suggesting that the inhibitory compounds act as a constitutive defense in $Z$. marina (Jakobsson-Thor et al. 2018), rather than as a inducible defense (Vergeer \& Develi 1997). Whether $Z$. marina shoots in other areas, outside the restricted study area on the Swedish west coast in JakobssonThor et al. (2018), also produce compounds with the same inhibitory effect towards L. zosterae is unknown.

The principal aim of the present study was to map the degree of L. zosterae infection on $Z$. marina along the naturally occurring salinity gradient along the Swedish coastline by quantifying both lesion coverage and $L$. zosterae cell concentration. In addition, $L$. zosterae infection experiments were conducted to test for differences in infection resistance of $Z$. marina shoots from sites with different salinity and pathogen pressure. The level of inhibitory compounds in the seagrass shoots from the different study sites was also investigated by exposing $L$. zosterae to seagrass extracts in laboratory growth assays. We hypothesized that the degree of L. zosterae infection would decrease along the salinity gradient of the Swedish coast, and that low-salinity populations with low pathogen pressure in situ would be more susceptible to infection than high-salinity populations that are more exposed to the pathogen. Furthermore, we 
hypothesized that $Z$. marina populations from the Baltic Sea would show lower chemical defense levels against $L$. zosterae compared to populations that are naturally exposed to higher pathogen pressure on the Swedish west coast.

\section{MATERIALS AND METHODS}

\subsection{Field survey}

A total of 480 Zostera marina shoots were collected along the Swedish coast by snorkeling between 25 August and 5 September 2014. Shoots were collected at 8 different areas along the coastline (Fjällbacka, Kungsbacka, Öresund, Trelleborg, Åhus, Kalmarsund, Västervik and Askö), and sampled from 3 meadows per area $(n=20$; Table 1$)$. All shoots were photographed on a light table for measurement of lesion coverage, transported on ice to the Tjärnö Marine Laboratory, Sweden, and finally stored at $-80^{\circ} \mathrm{C}$, pending analysis of Labyrinthula zosterae cell concentration and chemical defense.

\subsubsection{Lesion coverage and Labyrinthula zosterae cell concentration}

The pathogen load of $L$. zosterae and the disease symptoms were quantified by measuring $L$. zosterae cell concentration and lesion coverage for all collected shoots. Lesion coverage and cell concentration were also used to calculate the infection prevalence in each area by dividing the number of infected shoots by the total number of collected shoots. Lesion coverage was defined as percent coverage of necrotic tissue caused by L. zosterae infection on a whole $Z$. marina shoot (Burdick et al. 1993). ImageJ analysis of the photographs determined total shoot and lesion areas. Labyrinthula zosterae cell concentration in leaf tissue was quantified according to the protocol described in Bockelmann et al. (2013). The third leaf of each shoot was freeze-dried and homogenized using a mortar and pestle. DNA was extracted from a 2-3 mg sample using the Invisorb Spin Plant Mini Kit (Stratec Molecular) according to the manufacturer's protocol, with the exception that $1 \mu$ salmon sperm was added to saturate the silica columns with un-

Table 1. Average surface-water salinity (Snoeijs-Leijonmalm \& Andrén 2017) and collection depth in the sampled Zostera marina meadows. Lesion and Labyrinthula zosterae cell prevalence are given for each meadow. n/a: not applicable or missing values

\begin{tabular}{|c|c|c|c|c|c|c|}
\hline Area & Meadow & GPS coordinates & $\begin{array}{l}\text { Salinity } \\
\text { (PSU) }\end{array}$ & $\begin{array}{l}\text { Depth } \\
\text { (m) }\end{array}$ & $\begin{array}{c}\text { Lesion } \\
\text { prevalence }(\%)\end{array}$ & $\begin{array}{l}\text { Labyrinthula zosterae } \\
\text { cell prevalence }(\%)\end{array}$ \\
\hline \multirow[t]{3}{*}{ Askö } & 1 & $58^{\circ} 49.443^{\prime} \mathrm{N}, 17^{\circ} 37.682^{\prime} \mathrm{E}$ & 6 & $3-4$ & 60 & 20 \\
\hline & 2 & $58^{\circ} 49.589^{\prime} \mathrm{N}, 17^{\circ} 37.211^{\prime} \mathrm{E}$ & 6 & $4-5$ & 95 & 0 \\
\hline & 3 & $58^{\circ} 48.253^{\prime} \mathrm{N}, 17^{\circ} 39.053 \mathrm{E}$ & 6 & 3 & 95 & $\mathrm{n} / \mathrm{a}$ \\
\hline \multirow[t]{3}{*}{ Västervik } & 1 & $57^{\circ} 44.004^{\prime} \mathrm{N}, 16^{\circ} 43.007^{\prime} \mathrm{E}$ & 6 & $3-4$ & 85 & 20 \\
\hline & 2 & $57^{\circ} 45.336^{\prime} \mathrm{N}, 16^{\circ} 42.396^{\prime} \mathrm{E}$ & 6 & $3-4$ & 50 & 25 \\
\hline & 3 & $57^{\circ} 45.658^{\prime} \mathrm{N}, 16^{\circ} 42.460^{\prime} \mathrm{E}$ & 6 & $3-4$ & 70 & 0 \\
\hline \multirow[t]{3}{*}{ Kalmarsund } & 1 & $56^{\circ} 38.986^{\prime} \mathrm{N}, 16^{\circ} 27.605^{\prime} \mathrm{E}$ & 7 & 3 & 5 & 0 \\
\hline & 2 & $56^{\circ} 34.749^{\prime} \mathrm{N}, 16^{\circ} 24.478^{\prime} \mathrm{E}$ & 7 & $2.5-3$ & 0 & 0 \\
\hline & 3 & $56^{\circ} 39.225^{\prime} \mathrm{N}, 16^{\circ} 21.089^{\prime} \mathrm{E}$ & 7 & $3-4$ & 15 & 0 \\
\hline \multirow[t]{3}{*}{ Åhus } & 1 & $55^{\circ} 56.064^{\prime} \mathrm{N}, 14^{\circ} 19.469^{\prime} \mathrm{E}$ & 7 & 4 & 10 & 0 \\
\hline & 2 & $55^{\circ} 57.884^{\prime} \mathrm{N}, 14^{\circ} 23.170^{\prime} \mathrm{E}$ & 7 & 4 & 5 & 0 \\
\hline & 3 & $55^{\circ} 55.120^{\prime} \mathrm{N}, 14^{\circ} 20.352^{\prime} \mathrm{E}$ & 7 & 4 & 15 & 0 \\
\hline \multirow[t]{3}{*}{ Trelleborg } & 1 & $55^{\circ} 22.035^{\prime} \mathrm{N}, 13^{\circ} 10.018^{\prime} \mathrm{E}$ & 8 & $1.5-2$ & 15 & 0 \\
\hline & 2 & $55^{\circ} 21.640^{\prime} \mathrm{N}, 13^{\circ} 12.320^{\prime} \mathrm{E}$ & 8 & $1.5-2$ & 15 & 5 \\
\hline & 3 & $55^{\circ} 21.800^{\prime} \mathrm{N}, 13^{\circ} 11.817^{\prime} \mathrm{E}$ & 8 & $1.5-2$ & 0 & 0 \\
\hline \multirow[t]{3}{*}{ Öresund } & 1 & $55^{\circ} 39.270^{\prime} \mathrm{N}, 13^{\circ} 03.077^{\prime} \mathrm{E}$ & 10 & 2.5 & 25 & 56 \\
\hline & 2 & $55^{\circ} 59.845^{\prime} \mathrm{N}, 12^{\circ} 44.236^{\prime} \mathrm{E}$ & 10 & 1.5 & 6 & 25 \\
\hline & 3 & $56^{\circ} 03.286^{\prime} \mathrm{N}, 12^{\circ} 40.404^{\prime} \mathrm{E}$ & 10 & $3-4$ & 13 & 44 \\
\hline \multirow[t]{4}{*}{ Kungsbacka } & 1 & $57^{\circ} 22.897^{\prime} \mathrm{N}, 12^{\circ} 01.389^{\prime} \mathrm{E}$ & 20 & 4 & 100 & 100 \\
\hline & 2 & $57^{\circ} 23.006^{\prime} \mathrm{N}, 12^{\circ} 02.842^{\prime} \mathrm{E}$ & 20 & $3-3.5$ & 90 & 100 \\
\hline & 3 & $57^{\circ} 23.813^{\prime} \mathrm{N}, 12^{\circ} 01.423^{\prime} \mathrm{E}$ & 20 & $2.5-3$ & 30 & 100 \\
\hline & 4 & $57^{\circ} 24.397^{\prime} \mathrm{N}, 12^{\circ} 01.848^{\prime} \mathrm{E}$ & 20 & $2-3$ & $\mathrm{n} / \mathrm{a}$ & $\mathrm{n} / \mathrm{a}$ \\
\hline \multirow[t]{3}{*}{ Fjällbacka } & 1 & $58^{\circ} 36.449^{\prime} \mathrm{N}, 11^{\circ} 16.916^{\prime} \mathrm{E}$ & 25 & 1.5 & 95 & 100 \\
\hline & 2 & $58^{\circ} 37.045^{\prime} \mathrm{N}, 11^{\circ} 17.123^{\prime} \mathrm{E}$ & 25 & 1.5 & 100 & 75 \\
\hline & 3 & $58^{\circ} 36.115^{\prime} \mathrm{N}, 11^{\circ} 06.855^{\prime} \mathrm{E}$ & 25 & 3 & 100 & 100 \\
\hline
\end{tabular}


specified DNA. Real-time quantitative PCR (qPCR) was performed on a StepOne Plus qPCR machine (Applied Biosystems) as described in Bockelmann et al. (2013). Each sample ran in technical triplicates, and cycle threshold $\left(C_{\mathrm{T}}\right)$ was calculated with a fixed threshold of 0.05. A standard curve with known $L$. zosterae cell concentrations of 0.75 cells $\mu l^{-1}\left(C_{\mathrm{T}}\right.$ : $35.06 \pm 0.40 \mathrm{SD}), 7.5$ cells $^{-1} \mathrm{l}^{-1}\left(C_{\mathrm{T}}: 31.52 \pm 0.34 \mathrm{SD}\right)$, 75 cells $_{\mu l^{-1}}\left(C_{\mathrm{T}}: 28.10 \pm 0.32 \mathrm{SD}\right)$ and 750 cells $\mathrm{l}^{-1}$ $\left(C_{\mathrm{T}}: 24.04 \pm 0.32 \mathrm{SD}\right)$ ran alongside the samples on each qPCR plate. $C_{\mathrm{T}}$ values above 39 were not considered, and samples where the triplicates were exceeding a standard deviation of 0.5 were re-run or excluded from further analysis.

\subsubsection{Chemical defense assays}

All $Z$. marina shoots were extracted to determine if $Z$. marina populations from different salinities and pathogen pressure differ in their ability to inhibit $L$. zosterae growth. The shoots were freeze-dried and homogenized, and $500 \mu \mathrm{l}$ volumetric aliquots of each shoot $(\mathrm{n}=20)$ were extracted for $1 \mathrm{~h}$ in methanol and dichloromethane (1:1). Due to the variability in leaf numbers among the collected shoots, extraction was limited to the 3 youngest leaves of each shoot. The solvents were evaporated using a SpeedVac and stored at $-20^{\circ} \mathrm{C}$.

The L. zosterae strain used in the assay was isolated from Z. marina shoots collected in the Tjärnö archipelago about $32 \mathrm{~km}$ north of Fjällbacka in July 2014. The salinity in the Tjärnö archipelago is $\geq 20$ PSU and pathogenic $L$. zosterae have previously been isolated from this area (Jakobsson-Thor et al. 2018). A $3 \mathrm{~cm}$ piece of a $Z$. marina leaf with apparent lesions was surface sterilized with $0.5 \%$ sodium hypochlorite, rinsed in distilled water and finally soaked in autoclaved seawater. The piece was placed upon a sterile serum seawater agar (SSA) plate $(\varnothing=10 \mathrm{~cm})$ containing filtered $(0.2 \mu \mathrm{m})$ seawater, $12 \mathrm{~g}$ agar-agar $\mathrm{l}^{-1}, 1 \mathrm{~g}$ glucose $\mathrm{l}^{-1}, 0.1 \mathrm{~g}$ pepton $\mathrm{l}^{-1}, 0.1 \mathrm{~g}$ yeast extract $\mathrm{l}^{-1}, 3 \mathrm{mg}$ germanium dioxide $\mathrm{l}^{-1}, 10 \mathrm{ml}$ horse serum $\mathrm{l}^{-1}$ and $25 \mathrm{ml}$ streptomycin/penicillin $\mathrm{l}^{-1}(10000$ units penicillin and $10 \mathrm{mg}$ streptomycin $\mathrm{ml}^{-1}$ ). The $L$. zosterae culture was maintained in the dark at $25^{\circ} \mathrm{C}$ and transferred to a new agar plate every third week.

Labyrinthula zosterae growth on the $Z$. marina extracts was investigated using a bioassay described by Jakobsson-Thor et al. (2018). In short, each sample extract was redissolved in $500 \mu \mathrm{l}$ liquid growth medium, consisting of SSA minus agar, containing $1 \%$ dimethyl sulfoxide, and transferred into 6-well plates $(\varnothing=35 \mathrm{~mm})$. Labyrinthula zosterae covered agar plugs $(\varnothing=7 \mathrm{~mm})$ were placed face down in the middle of each well. Plates were incubated in the dark at $25^{\circ} \mathrm{C}$ for $27 \mathrm{~h}$. The L. zosterae colony growing attached to the bottom of each well was outlined and photographed, and the area was calculated using ImageJ software. Controls $(\mathrm{n}=60)$ received growth medium without $Z$. marina extract.

\subsection{Infection experiment}

An infection experiment was performed to investigate whether the susceptibility of $Z$. marina to wasting disease differs between populations from different salinities. Zostera marina shoots, including rhizomes, were collected in early June 2015 from the same meadows in Askö, Kalmarsund, Trelleborg, Kungsbacka and Fjällbacka as for the field survey, with the exception that shoots were collected from meadow 4 instead of meadow 3 in Kungsbacka (Table 1). Shoots were only collected from meadows 1 and 2 in Askö. Living shoots were transported to the Tjärnö Marine Laboratory in seawater, and acclimated to $20^{\circ} \mathrm{C}$ and $25 \mathrm{PSU}$ over $15 \mathrm{~d}$. Shoots were placed in individual $6 \mathrm{l}$ containers in an outdoor flowthrough system with filtered $(10 \mu \mathrm{m})$ seawater at $20^{\circ} \mathrm{C}$ and $25 \mathrm{PSU}$ ( \pm 1 PSU). The rhizome was submerged in $600 \mathrm{ml}$ sterilized sediment and the middle part of the third youngest leaf $(n=15$ from each meadow) was infected with a bandage containing $L$. zosterae cells. The bandages were prepared with plugs $(\varnothing=5 \mathrm{~mm})$ taken from SSA plates (with or without $L$. zosterae), and attached using silica tubing enclosed around the leaves. Labyrinthula zosterae used for infection was isolated from $Z$. marina leaves collected haphazardly in the Tjärnö archipelago in May 2015 as described in Section 2.1.2. Ten shoots from each meadow with $L$. zosterae-free bandages served as controls. After $9 \mathrm{~d}$ of infection, shoots were photographed for calculation of lesion coverage.

\subsection{Labyrinthula zosterae identification}

DNA was extracted from L. zosterae isolated (as in Section 2.1.1) from the same meadow as previous isolates in the present study in the Tjärnö archipelago in August 2015. Cultures growing on SSA plates were carefully scraped off the agar and extracted with an Invitek tissue kit according to the manufacturer's protocol. The small subunit (18S) ribosomal RNA gene was sequenced following Bockelmann et al. 
(2012). In short, the $18 \mathrm{~S} F$ and R universal primers (Medlin et al. 1988), together with the 3 internal primers described in Bockelmann et al. (2012), were used to obtain the entire amplicon. Sanger sequencing was performed on an ABI 3130xl genetic analyzer (Applied Biosystems). The sequence was submitted to NCBI GenBank under accession number MG333730, and the sequence was subjected to a standard nucleotide BLAST search against the NCBI GenBank database.

\subsection{Statistical analyses}

The data set from the field survey did not fulfill the assumptions for linear regression analysis (i.e. homoscedastcity and normally distributed residuals), and therefore a non-parametric test (Spearman's rank correlation; Underwood 1997) was used to investigate whether data on lesion coverage (\%) and $L$. zosterae cell concentration (cells $\mathrm{mg}^{-1} \mathrm{Z}$. marina dry mass) are correlated with the average surface-water salinity (Snoeijs-Leijonmalm \& Andrén 2017) in natural Z. marina populations.

Labyrinthula zosterae growth in the chemical defense assays was measured as percent growth in wells with $Z$. marina extracts relative to growth in control wells, and analyzed using nested ANOVA with area (8 levels) as a random factor, and meadow (3 levels) as a random factor nested within area (see Table 2). Data on lesion coverage from the infection experiment were analyzed using nested ANOVA with area (5 levels) as a random factor, and meadow (3 levels) as a random factor nested within area (see Table 3).

Prior to the ANOVAs, data were tested for homogeneity of variance with a Cochran's test (Underwood 1997). Data for the infection experiment and the chemical defense assays did not meet the requirement of homogeneity (infection experiment: $C_{\text {calc }}=0.165$, $C_{\text {crit }}=0.143$; chemical defense assays: $C_{\text {calc }}=0.107$,

Table 2. Chemical defense assays. Nested ANOVA of data on the inhibitory effect of extracts from Zostera marina shoots collected from different meadows within different salinity areas on Labyrinthula zosterae growth (\% relative to control). Bold indicates significance $(\mathrm{p}<0.05)$

\begin{tabular}{|lrcccl|}
\hline $\begin{array}{l}\text { Source of } \\
\text { variation }\end{array}$ & df & MS & $F$ & p & Error term \\
\hline Area & 7 & 1585.516 & 5.983 & $\mathbf{0 . 0 1 5}$ & Meadow (area) \\
Meadow (area) & 16 & 265.018 & 0.831 & 0.650 & Residual \\
Residual & 456 & 318.906 & & & \\
\hline
\end{tabular}

Table 3. Infection experiment. Nested ANOVA of data on lesion coverage (\% relative to controls) on Zostera marina shoots from different $Z$. marina meadows within different salinity areas following infection by Labyrinthula zosterae. Bold indicates significance $(\mathrm{p}<0.05)$

\begin{tabular}{|lrrccl}
\hline $\begin{array}{l}\text { Source of } \\
\text { variation }\end{array}$ & df & MS & $F$ & p & Error term \\
\hline Area & 4 & 4347.916 & 6.978 & $\mathbf{0 . 0 0 6}$ & Meadow (area) \\
Meadow (area) & 10 & 623.089 & 2.534 & $\mathbf{0 . 0 0 7}$ & Residual \\
Residual & 210 & 245.856 & & & \\
\hline
\end{tabular}

$\left.C_{\text {crit }}=0.074\right)$. However, due to the large number of groups and replicates, the ANOVA is robust towards heterogeneous variances (Underwood 1997) and therefore untransformed data were analyzed. Means were compared using a Student-NewmanKeuls (SNK) test (Underwood 1997).

\section{RESULTS}

\subsection{Prevalence of lesion coverage and Labyrinthula zosterae cells}

Overall, Zostera marina meadows in high-salinity areas had a higher prevalence of lesions and Labyrinthula zosterae cells compared to meadows in low-salinity areas (Table 1). Most of the shoots from Fjällbacka and Kungsbacka had lesions, while lesion were less prevalent at lower salinities (7-10 PSU) along the Swedish coast in Öresund, Trelleborg, Åhus and Kalmarsund (Fig. 1A). However, lesions were highly prevalent in $Z$. marina populations at 6 PSU in Västervik and Askö (Fig. 1A). The prevalence of $L$. zosterae cells followed a similar pattern as for lesion prevalence. The pathogen was detected in most of the shoots from Fjällbacka and Kungsbacka (Fig. 1B), and L. zosterae cell prevalence was lower at lower salinities in Öresund and Trelleborg, while no

L. zosterae cells were found in Åhus or Kalmarsund. In Västervik and Askö, L. zosterae cells occurred in some of the sampled $Z$. marina shoots.

\subsection{Lesion coverage and Labyrinthula zosterae cell concentration}

The pathogen load and symptoms of $L$. zosterae infection, quantified as L. zosterae cell concentration and lesion coverage, respectively, were highest on $Z$. marina shoots from highsalinity populations, and significantly correlated 

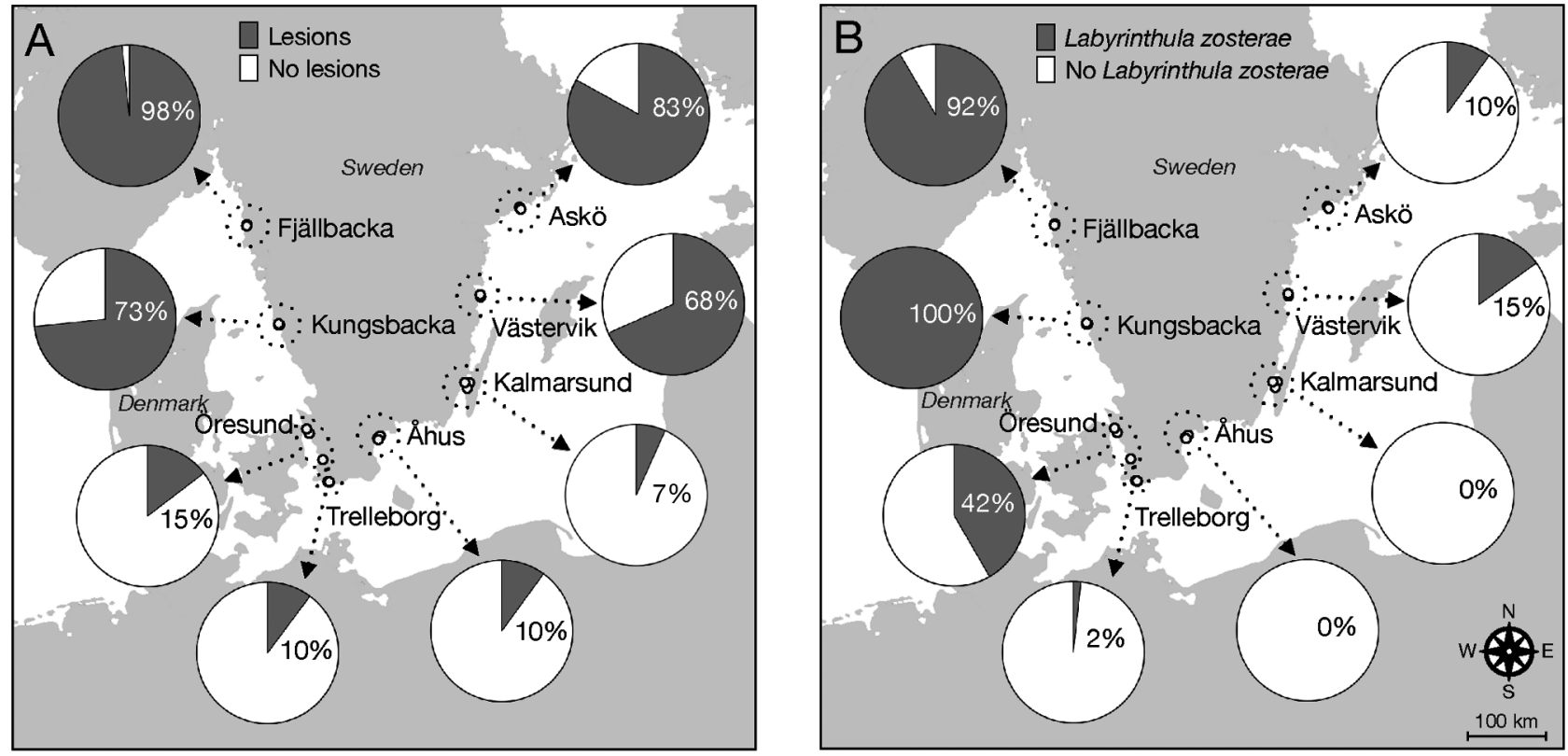

Fig. 1. Field survey. Prevalence of Labyrinthula zosterae infection on Zostera marina shoots along the Swedish coast, measured as (A) lesion prevalence and (B) L. zosterae prevalence. Pie charts show all samples $(\mathrm{n}=60)$ collected from 3 meadows per area. Prevalence values are shown for infected shoots

with salinity (lesion coverage: Spearman's rho $=0.182$, df $=479, \mathrm{p}<$ $0.0001 ;$ L. zosterae cell concentration: Spearman's rho $=0.710, \mathrm{df}=459, \mathrm{p}<$ 0.0001; Fig. 2B).

Due to the high number of $Z$. marina shoots without lesions or $L$. zosterae cells, the reported lesion coverage and L. zosterae cell concentration below are limited to infected shoots only. Lesion coverage varied among the investigated shoots and covered $0.2-48 \%$ of the shoots from meadows in salinities $\geq 20$ PSU (Fjällbacka and Kungsbacka), and $\leq 6 \%$ in salinities between 7 and 10 PSU (Fig. 3A). In areas with 6 PSU (Västervik and Askö), lesions covered 0.1$11 \%$ of the shoots (Fig. 3A). Labyrinthula zosterae cell concentration also varied among the shoots. In the highsalinity meadows (Fjällbacka and Kungsbacka; $\geq 20$ PSU), L. zosterae

Fig. 2. Relationship between (A) lesion coverage (\%) and (B) Labyrinthula zosterae cell concentration (cells $\mathrm{mg}^{-1}$ Zostera marina dry mass) in $Z$. marina and surface salinity
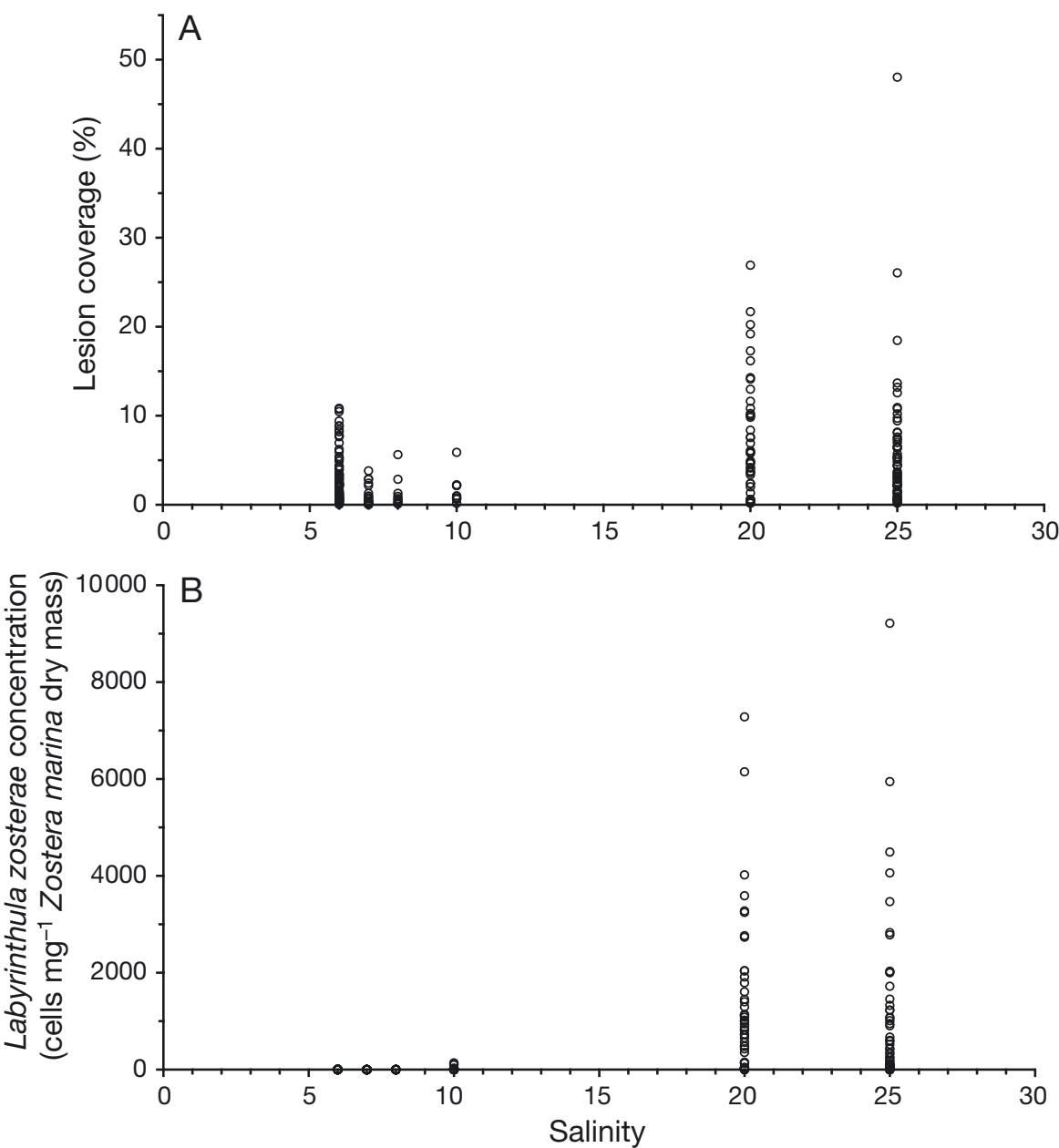

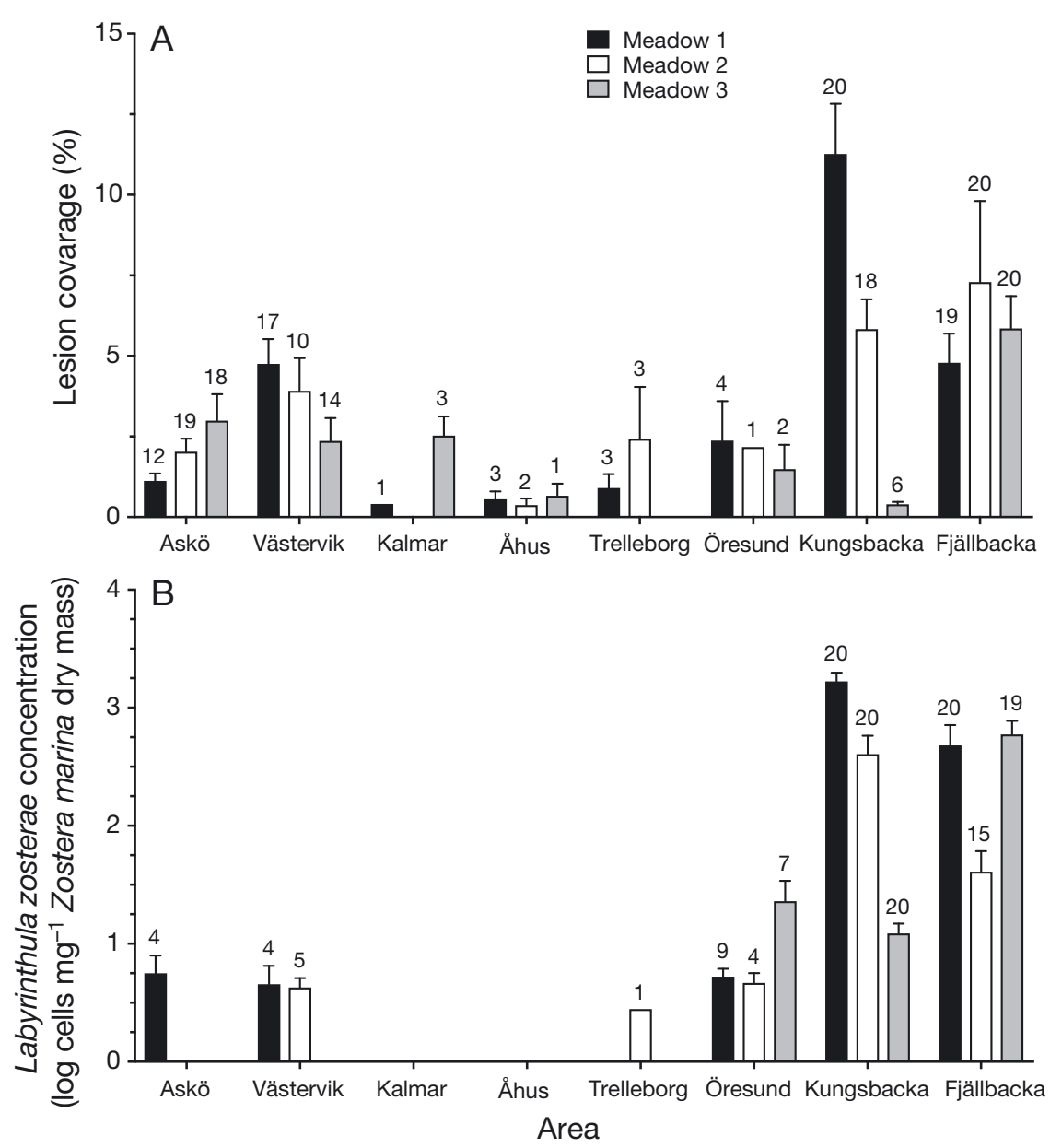

Fig. 3. Field survey. Labyrinthula zosterae infection along a salinity gradient from 6 to 25 PSU measured as (A) lesion coverage (\%) and (B) L. zosterae cell concentration (cells $\mathrm{mg}^{-1}$ Zostera marina dry mass). Shoots were collected from 3 meadows per area along the Swedish coast. Data are shown only for infected $Z$. marina shoots. Number of replicates per meadow is given above respective bars. Error bars show \pm SEM

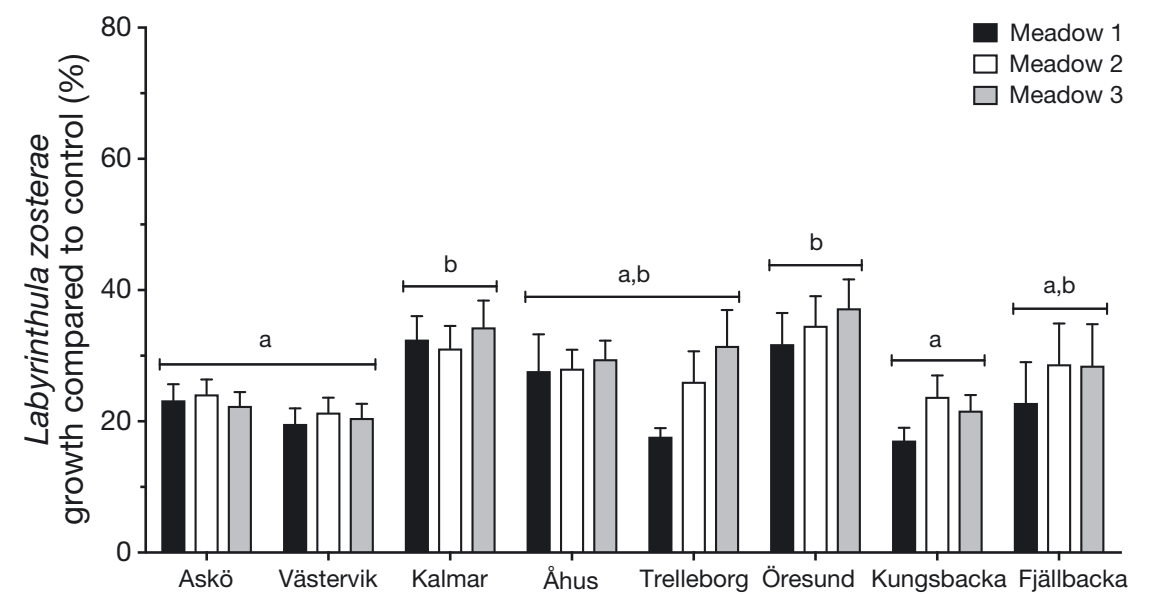

Fig. 4. Chemical defense assay. Labyrinthula zosterae growth on extracts of Zostera marina shoots relative to growth on control media. Zostera marina shoots were collected from 3 meadows per area along the Swedish coast. Different letters above bars indicate significant differences among areas based on the Student-Newman-Keuls test $(p<0.05)$. Error bars show \pm SEM, $n=20$ cell concentration ranged between 2.80 and 9217.76 cells $\mathrm{mg}^{-1}$ Z. marina dry mass, and in Öresund (10 PSU) this ranged between 3.21 and 138.50 cells $\mathrm{mg}^{-1} Z$. marina dry mass. Labyrinthula zosterae cell concentration was similar on shoots in the 2 areas with the lowest investigated salinity, Västervik and Askö (6 PSU), and ranged from 1.93 to 10.94 cells $\mathrm{mg}^{-1}$ Z. marina dry mass (Fig. 3B).

\subsection{Chemical defense}

Natural concentrations of extracts from all $Z$. marina shoots strongly inhibited L. zosterae growth (Fig. 4). Overall, pathogen growth in media containing $Z$. marina extracts was on average $26.5 \pm 0.8 \%$ SE relative to growth on control media. There was also a statistically significant difference in growth inhibition depending on the collection area of the shoots (Table 2). The SNK test revealed that $Z$. marina extracts from Askö, Västervik and Kungsbacka inhibited $L$. zosterae growth significantly $(\mathrm{p}<$ $0.05)$ more compared to extracts from Öresund and Kalmarsund. No significant difference was detected between shoots from different meadows within an area (Table 2).

\subsection{Infection experiment}

All Z. marina shoots, independent of population origin, developed lesions in a high-salinity environment when exposed to L. zosterae (Fig. 5). In addition, there was a significant difference in susceptibility between different areas (Table 3). Shoots from Askö showed significantly (SNK test, $\mathrm{p}<0.05)$ larger lesion coverage (40.1 $\pm 2.5 \% \mathrm{SE}$ ) compared to shoots from other areas $(21.1 \% \pm 1.0 \mathrm{SE})$. There was also a significant difference between meadows within an area (Table 3). Susceptibility to L. zosterae infection differed significantly be- 


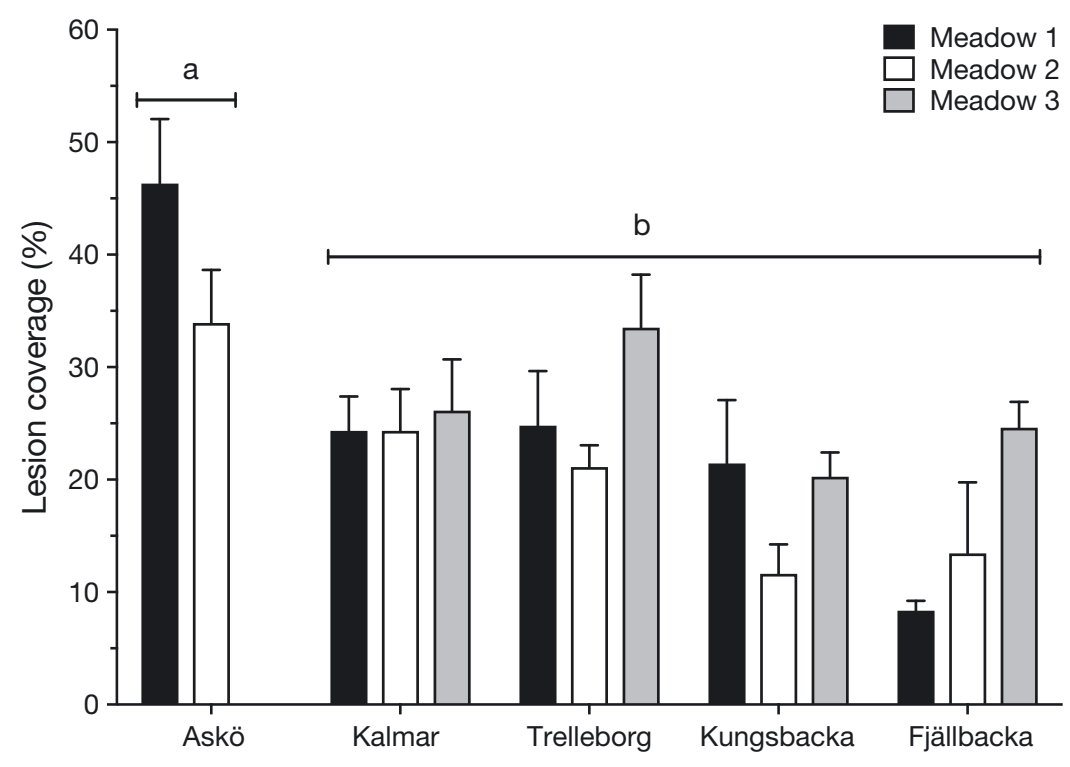

Fig. 5. Infection experiment. Lesion coverage (\%) on Zostera marina shoots following $9 \mathrm{~d}$ of infection by Labyrinthula zosterae. Zostera marina shoots were collected from 3 different meadows within 5 different areas along the Swedish coast. Only 2 meadows were investigated from Askö. Different letters above bars indicate significant differences between areas based on the

Student-Newman-Keuls test $(\mathrm{p}<0.05)$. Error bars show \pm SEM, $n=15$

influence the interaction between Zostera marina and the pathogen in situ (Sullivan et al. 2018). Here, we present the first study investigating $L$. zosterae infection in natural $Z$. marina populations along a large-scale $(>1000 \mathrm{~km})$ geographical salinity gradient.

The results show that prevalence of seagrass wasting disease symptoms and L. zosterae pathogen load follow salinity in most $Z$. marina meadows, and that lesion coverage and L. zosterae cell concentration correlate positively with salinity. These findings corroborate previous results from laboratory experiments showing that lesion size increases with increasing salinity (McKone \& Tanner 2009), and that Labyrinthula spp. growth and infection rate is low or close to zero at salinities below 10 PSU (Muehlstein et al. 1988, Short et al. 1988, Martin et al. 2009). Furthermore, in the highsalinity areas, pathogen prevalence

tween meadows in both Askö and Fjällbacka. No difference was detected between meadows in the other investigated areas.

\subsection{Labyrinthula zosterae identification}

We extracted a partial 18S sequence (1084 bp) from an $L$. zosterae culture isolated from $Z$. marina. The sequence showed a $99 \%$ identity to 20 partial $18 \mathrm{~S}$ rDNA sequences classified as L. zosterae from northern Europe (Bergmann et al. 2011, Bockelmann et al. 2012), Italy (Bockelmann et al. 2012) and the USA (Bergmann et al. 2011, Martin et al. 2016). Of these isolates, 3 were classified as pathogenic following positive infection experiments (Martin et al. 2016), whereas the remaining 17 were isolated from Z. marina leaves with visible lesions without further pathogenicity testing (Bergmann et al. 2011, Bockelmann et al. 2012).

\section{DISCUSSION}

Although the wasting disease pathogen Labyrinthula zosterae can have a devastating impact on seagrass populations (reviewed in Sullivan et al. 2013), little is still known about how environmental factors led to disease symptoms in $89 \%$ of the $Z$. marina shoots, whereas only about $40 \%$ of the infected shoots developed lesions in Öresund (10 PSU). This indicates, in agreement with previous findings (Burdick et al. 1993), that L. zosterae disease cannot be maintained at lower salinities.

Although infection by L. zosterae on Z. marina generally decreased in plants from populations growing in areas with decreasing salinity, we also found that L. zosterae was present in eelgrass plants from 2 areas in the low-salinity environment ( 6 PSU). This is, to our knowledge, the first report of L. zosterae in the Baltic Proper, an area with constantly low salinity, although other Labyrinthula spp. have been isolated from Z. marina in the Baltic Sea in Åland and Finland (Bockelmann et al. 2013, Lindholm et al. 2016). The mean lesion prevalence was high among the Z. marina meadows in Askö and Västervik, but it did not correlate with $L$. zosterae cell concentrations. Labyrinthula zosterae cells were only isolated from a few $Z$. marina shoots in these meadows, and at a relatively low concentration compared to the average cell concentration found in the high-salinity populations. This implies that the L. zosterae strain(s) existing in low-salinity meadows could be more virulent than their high-salinity counterparts, resulting in pronounced disease symptoms despite the low cell concentration. If this is the case, which remains to be 
further demonstrated, it would question the notion that low-salinity environments can act as refuges for Z. marina from L. zosterae infection (Young 1943, McKone \& Tanner 2009, Jakobsson-Thor et al. 2018). Differences between lesion prevalence and L. zosterae cells prevalence have been found in previous field studies that have applied a qPCR assay for identification and quantification of L. zosterae (Bockelmann et al. 2013, Jakobsson-Thor et al. 2018). It is possible that lesions in the low-salinity $Z$. marina populations are a result of factors other than the presence of L. zosterae; e.g. suboptimal temperature and salinity levels have been found to increase necrotic tissue in Z. marina (Biebl \& McRoy 1971, Collier \& Waycott 2014). However, environmentally induced necrosis usually spreads from the bottom or top of the leaves, whereas wasting disease often are indicated by lesions in the middle of the leaves with surrounding green tissue (Muehlstein et al. 1988). Alternatively, another pathogen, e.g. an unknown Labyrinthula sp. not targeted with the primers used in the qPCR assay, could cause the disease symptoms. Isolation and investigation of the microbial community in these $Z$. marina populations could identify if other possible pathogens are present in the system.

The degree of infection is known to correlate with salinity in several marine host-pathogen systems, indicating that many marine pathogens are sensitive to low salinities (Eiler et al. 2006, Johansson et al. 2006, Bushek et al. 2012). However, because host-pathogen interactions are dynamic systems, evolutionary and ecological changes can shift the balance between pathogen success and host survival (Galvani 2003). An adaptation to lower salinity has, for example, been seen in experimental studies of the pathogenic marine bacterium Vibrio vulnificus Farmer 1980, where it was shown that this halophyte can increase its survival at a lethal salinity level (0.04\% $\mathrm{NaCl}$ ) during its exponential growth phase after a short adaptation to low salinity $(0.12 \% \mathrm{NaCl})$ (Wong \& Liu 2008). Additionally, a non-pathogenic Labyrinthula sp. has been identified in both high (20-25 PSU) and low (5 PSU) salinities (Bockelmann et al. 2012), demonstrating a wide salinity tolerance in this genus. It is therefore possible that a strain of $L$. zosterae has adapted to the low salinity in the Baltic Sea. Further studies investigating pathogen performance in different salinities, as well their effects on the seagrass host, could provide a better understanding of the adaptation and ecological significance of lowsalinity L. zosterae strains. Phylogenetic analysis should also be included to determine whether the strain from the Baltic Sea is closely related to other pathogenic L. zosterae strains in northern Europe (Bockelmann et al. 2012), including the L. zosterae strain isolated and sequenced from the Swedish west coast in the present study.

The varying degree of $L$. zosterae infection in the investigated seagrass meadows is not primarily caused by differences in infection resistance among the $Z$. marina populations. Overall, the L. zosterae success in the infection experiment corroborates previous data showing that $Z$. marina shoots from lowsalinity areas will develop lesions in a high-salinity environment (Jakobsson-Thor et al. 2018). The infection experiment further showed that all $Z$. marina populations, except those populations from Askö that showed a somewhat higher degree of susceptibility, were equally susceptible to infection by L. zosterae, implying no consistent correlation between pathogen pressure in situ and disease resistance. In contrast, the results from a previous study, on a smaller geographical scale, showed that uninfected $Z$. marina shoots from low salinity are somewhat more susceptible to $L$. zosterae infection compared with shoots from high salinity with higher pathogen pressure (Jakobsson-Thor et al. 2018). The underlying reasons, e.g. possible local adaptation in terms of seagrass resistance mechanisms against the pathogen, for the relatively minor, but still statistically significant, differences in infection susceptibility among eelgrass meadows at Askö remains to be further investigated.

Interestingly, all Z. marina shoots investigated in this study produced chemical compounds that strongly inhibited L. zosterae growth irrespective of the degree of infection. The lack of a clear correlation between infection degree and presence of inhibitory compounds indicates that chemical defense production is not induced by a high pathogen pressure, in contrast to what has previously been suggested for this host-pathogen interaction (Buchsbaum et al. 1990, Vergeer et al. 1995). Instead, our findings corroborate the results of a previous study on chemicalbased resistance against $L$. zosterae in natural $Z$. marina populations, which suggested that there are inhibitory compounds that function as a constitutive defense across $Z$. marina meadows in different types of environments (Jakobsson-Thor et al. 2018). As previously suggested by Jakobsson-Thor et al. (2018), identification of the inhibitory compounds in the $Z$. marina extracts is crucial to better understand the function of these compounds within the plant and to further investigate possible local adaptations in terms of chemical defenses towards L. zosterae in eelgrass populations. Preferably, the identification of 
inhibitory/defensive compounds should be accomplished using an open approach, such as a bioassayguided fractionation (e.g. Kubanek et al. 2003, Trevathan-Tackett et al. 2015), without preconceived notions about the identity of the compound with inhibitory effect.

In conclusion, this is the first study to investigate seagrass wasting disease in natural $Z$. marina populations over a large-scale $(>1000 \mathrm{~km})$ salinity gradient. Our results show that, overall, wasting disease follow salinity, as previously reported from laboratory experiments (Burdick et al. 1993, McKone \& Tanner 2009). However, the results also show that a salinity as low as 6 PSU does not always exclude $L$. zosterae infection in $Z$. marina meadows. Labyrinthula zosterae cells were detected in 2 low-salinity areas, where lesions symptomatic of wasting disease were also highly prevalent. Thus, it is possible that $L$. zosterae strains may adapt to low salinity in parts of the Baltic Sea. This could, in turn, imply a wider distribution of L. zosterae, which includes areas that previously have been considered to constitute refuges from the pathogen for $Z$. marina.

Acknowledgements. This work was funded by the Swedish Research Council FORMAS (No. 2011-1193), and additional support was provided by the Linnaeus Centre for Marine Evolutionary Biology (CeMEB) and the Centre for Marine Chemical Ecology (CeMaCE) at the University of Gothenburg, and by the Rådman och Fru Ernst Collianders Stiftelse. Thanks to Ylva Durland and Gunnar Cervin for field and experimental assistance, and to Janina Brakel for $L$. zosterae sequencing and phylogenetic analysis.

\section{LITERATURE CITED}

Barbier EB, Hacker SD, Kennedy C, Koch EW, Stier AC, Silliman BR (2011) The value of estuarine and coastal ecosystem services. Ecol Monogr 81:169-193

Bergmann N, Fricke B, Schmidt MC, Tams V and others (2011) A quantitative real-time polymerase chain reaction assay for the seagrass pathogen Labyrinthula zosterae. Mol Ecol Resour 11:1076-1081

Biebl R, McRoy CP (1971) Plasmatic resistance and rate of respiration and photosynthesis of Zostera marina at different salinities and temperatures. Mar Biol 8:48-56

Bishop N, Martin DL, Ross C (2017) Effects of multi-stress exposure on the infection dynamics of a Labyrinthula sp.-turtle grass pathosystem. Mar Ecol Prog Ser 581: 119-133

Bockelmann AC, Beining K, Reusch TBH (2012) Widespread occurrence of endophytic Labyrinthula spp. in northern European eelgrass Zostera marina beds. Mar Ecol Prog Ser 445:109-116

Bockelmann AC, Tams V, Ploog J, Schubert PR, Reusch TBH (2013) Quantitative PCR reveals strong spatial and temporal variation of the wasting disease pathogen, Labyrinthula zosterae in northern European eelgrass
(Zostera marina) beds. PLOS ONE 8:e62169

* Boström C, Baden S, Bockelmann AC, Dromph K and others (2014) Distribution, structure and function of Nordic eelgrass (Zostera marina) ecosystems: implications for coastal management and conservation. Aquat Conserv 24:410-434

* Buchsbaum RN, Short FT, Cheney DP (1990) Phenolic-nitrogen interactions in eelgrass, Zostera marina L.: possible implications for disease resistance. Aquat Bot 37:291-297

* Burdick DM, Short FT, Wolf J (1993) An index to assess and monitor the progression of wasting disease in eelgrass Zostera marina. Mar Ecol Prog Ser 94:83-90

* Bushek D, Ford SE, Burt I (2012) Long-term patterns of an estuarine pathogen along a salinity gradient. J Mar Res 70:225-251

* Collier CJ, Waycott M (2014) Temperature extremes reduce seagrass growth and induce mortality. Mar Pollut Bull 83: 483-490

Duarte CM, Middelburg JJ, Caraco N (2005) Major role of marine vegetation on the oceanic carbon cycle. Biogeosciences 2:1-8

*Eiler A, Johansson M, Bertilsson S (2006) Environmental influences on Vibrio populations in northern temperate and boreal coastal waters (Baltic and Skagerrak Seas). Appl Environ Microbiol 72:6004-6011

Galvani AP (2003) Epidemiology meets evolutionary ecology. Trends Ecol Evol 18:132-139

* Harvell CD, Kim K, Burkholder JM, Colwell RR and others (1999) Emerging marine diseases: climate links and anthropogenic factors. Science 285:1505-1510

Hay ME, Fenical W (1988) Marine plant-herbivore interactions: the ecology of chemical defense. Annu Rev Ecol Syst 19:111-145

Jakobsson-Thor S, Toth GB, Brakel J, Bockelmann AC, Pavia H (2018) Seagrass wasting disease varies with salinity and depth in natural Zostera marina populations. Mar Ecol Prog Ser 587:105-115

* Johannesson K, Smolarz K, Grahn M, André C (2011) The future of Baltic Sea populations: local extinction or evolutionary rescue? Ambio 40:179-190

Johansson M, Eiler A, Tranvik L, Bertilsson S (2006) Distribution of the dinoflagellate parasite Parvilucifera infectans (Perkinsozoa) along the Swedish coast. Aquat Microb Ecol 43:289-302

*Kubanek J, Jensen PR, Keifer PA, Sullards MC, Collins DO, Fenical W (2003) Seaweed resistance to microbial attack: a targeted chemical defense against marine fungi. Proc Natl Acad Sci USA 100:6916-6921

* Levin DA (1971) Plant phenolics: an ecological perspective. Am Nat 105:157-181

* Lindholm T, Lindqvist C, Sjöqvist C (2016) Occurrence and activity of slime nets, Labyrinthula sp. among aquatic plants in cold and oligohaline Baltic Sea waters. Ann Bot Fenn 53:139-143

Martin DL, Boone E, Caldwell MM, Major KM, Boettcher AA (2009) Liquid culture and growth quantification of the seagrass pathogen, Labyrinthula spp. Mycologia 101: 632-635

*Martin DL, Chiari Y, Boone E, Sherman TD and others (2016) Functional, phylogenetic and host-geographic signatures of Labyrinthula spp. provide for putative species delimitation and a global-scale view of seagrass wasting disease. Estuaries Coasts 39:1403-1421

McKone KL, Tanner CE (2009) Role of salinity in the susceptibility of eelgrass Zostera marina to the wasting disease 
pathogen Labyrinthula zosterae. Mar Ecol Prog Ser 377: 123-130

Medlin L, Elwood HJ, Stickel S, Sogin ML (1988) The characterization of enzymatically amplified eukaryotic 16Slike rRNA-coding regions. Gene 71:491-499

Muehlstein LK, Porter D, Short FT (1988) Labyrinthula sp., a marine slime mold producing the symptoms of wasting disease in eelgrass, Zostera marina. Mar Biol 99:465-472

Muehlstein LK, Porter D, Short FT (1991) Labyrinthula zosterae sp. nov., the causative agent of wasting disease of eelgrass, Zostera marina. Mycologia 83:180-191

Nejrup LB, Pedersen MF (2008) Effects of salinity and water temperature on the ecological performance of Zostera marina. Aquat Bot 88:239-246

Nordlund LM, Koch EW, Barbier EB, Creed JC (2016) Seagrass ecosystem services and their variability across genera and geographical regions. PLOS ONE 11:e0163091

Orth RJ, Heck KL, Vanmontfrans J (1984) Faunal communities in seagrass beds: a review of the influence of plant structure and prey characteristics on predator-prey relationship. Estuaries 7:339-350

* Petersen HE (1934) Wasting disease of eelgrass (Zostera marina). Nature 134:143-144

Renn CE (1935) A mycetozoan parasite of Zostera marina. Nature 135:544-545

Short FT, Mathieson AC, Nelson JI (1986) Recurrence of the eelgrass wasting disease at the border of New Hampshire and Maine, USA. Mar Ecol Prog Ser 29:89-92

Short FT, Ibelings BW, den Hartog C (1988) Comparison of a current eelgrass disease to the wasting disease in the 1930s. Aquat Bot 30:295-304

Snoeijs-Leijonmalm P, Andrén E (2017) Why is the Baltic Sea so special to live in? In: Snoeijs-Leijonmalm P, Schubert H, Radziejewska T (eds) Biological oceanography of the Baltic Sea. Springer, Dordrecht, p 23-84

Editorial responsibility: Morten Pedersen,

Roskilde, Denmark
Sullivan BK, Sherman TD, Damare VS, Lilje O, Gleason FH (2013) Potential roles of Labyrinthula spp. in global seagrass population declines. Fungal Ecol 6:328-338

* Sullivan BK, Trevathan-Tackett SM, Neuhauser S, Govers LL (2018) Host-pathogen dynamics of seagrass diseases under future global change. Mar Pollut Bull 134:75-88

* Trevathan SM, Kahn A, Ross C (2011) Effects of short-term hypersalinity exposure on the susceptibility to wasting disease in the subtropical seagrass Thalassia testudinum. Plant Physiol Biochem 49:1051-1058

* Trevathan-Tackett SM, Lane AL, Bishop N, Ross C (2015) Metabolites derived from the tropical seagrass Thalassia testudinum are bioactive against pathogenic Labyrinthula sp. Aquat Bot 122:1-8

Underwood AJ (1997) Experiments in ecology: their logical design and interpretation using analysis of variance. Cambridge University Press, Cambridge

V Vergeer LHT, Develi A (1997) Phenolic acids in healthy and infected leaves of Zostera marina and their growth-limiting properties towards Labyrinthula zosterae. Aquat Bot 58:65-72

* Vergeer LHT, Aarts TL, de Groot JD (1995) The 'wasting disease' and the effect of abiotic factors (light intensity, temperature, salinity) and infection with Labyrinthula zosterae on the phenolic content of Zostera marina shoots. Aquat Bot 52:35-44

Wong HC, Liu SH (2008) Characterization of the low-salinity stress in Vibrio vulnificus. J Food Prot 71:416-419

Y Young EL (1943) Studies on Labyrinthula. The etiologic agent of the wasting disease of eel-grass. Am J Bot 30: 586-593

Zidorn C (2016) Secondary metabolites of seagrasses (Alismatales and Potamogetonales; Alismatidae): chemical diversity, bioactivity, and ecological function. Phytochemistry 124:5-28

Submitted: September 13, 2018; Accepted: March 2, 2019

Proofs received from author(s): March 30, 2019 